\title{
GAMBARAN WORK ENGAGEMENT PADA KARYAWAN DI PT EG (MANUFACTURING INDUSTRY)
}

\author{
Rian Pri ${ }^{1}$, Zamralita ${ }^{2}$ \\ ${ }^{1}$ Fakultas Psikologi, Universitas Tarumanagara \\ Email : rianpri13@gmail.com \\ ${ }^{2}$ Fakultas Psikologi, Universitas Tarumanagara \\ Email : zamralita@fpsi.untar.ac.id
}

\begin{abstract}
ABSTRAK
PT EG adalah salah satu perusahaan yang bergerak di bidang manufacturing. Saat ini PT EG telah menunjukkan perkembangan yang sangat pesat. Keberhasilan PT EG tentunya tidak terlepas dari karyawan sebagai mitra kerja yang terbukti telah memiliki kontribusi besar dalam setiap kegiatan untuk kelangsungan PT. EG. Dalam melaksanakan tugasnya, karyawan di PT EG menunjukkan antusiasme dan bersedia mengaplikasikan energi yang dimiliki untuk menyelesaikan tuntutan kerja yang diberikan, tidak sedikit pula karyawan yang merasa bangga terhadap pekerjaannya. Kondisi ini menunjukkan adanya work engagement yang dimiliki antara karyawan. Work engagement didefinisikan sebagai keadaan dimana seseorang mampu berkomitmen dengan organisasi baik secara emosional maupun intelektual. Dengan demikian peneliti memutuskan untuk melakukan studi tentang work engagement pada karyawan di PT EG. Metode yang digunakan dalam penelitian ini adalah kuantitaf non experimental dengan metode deskriptif. Data diperoleh melalui kuesioner work engagement yang diadaptasi dari Utrech Work Engagement Scale (UWES) yang berisi 17 butir pernyataan (Schaufeli dan Bakker, 2004). Hasil penelitian menunjukkan bahwa tingkat work engagement di antara karyawan di PT EG tergolong tinggi $(M=5.57)$. Berikut adalah nilai rata-rata dimensi work engagement, vigour $(M=5,676)$, dedication $(M=5,715)$, absorption $(M=5,36)$. Hal ini menunjukkan bahwa semua karyawan memiliki work engagement yang tinggi, yang berarti mereka bisa mencapai tujuan mereka, sehingga dapat memberi dampak pada keberhasilan PT. EG.
\end{abstract}

Kata kunci : work engagement, Utrech Work Engagement Scale (UWES), karyawan, kinerja

\section{PENDAhuluan}

Sumber daya manusia merupakan aset penting di dalam suatu organisasi. Bagi organisasi, memiliki sumber daya manusia yang produktif akan menghasilkan kinerja yang diharapkan mampu berdampak pada kelangsungan hidup maupun kemajuan organisasi. Dengan memandang karyawan sebagai aset, perusahaan harus memberikan perhatian khusus bagi karyawannya dan selalu berusaha untuk memberikan kenyamanan, serta memastikan keamanan karyawan selama bekerja, sehingga karyawan dapat merasa pekerjaan mereka sebagai salah satu pengalaman hidup yang menyenangkan. Pandangan ini membuat organisasi saat ini fokus untuk dapat membuat karyawan mereka terikat dengan pekerjaan dan organisasinya.

Keterikatan karyawan dengan pekerjaannya atau yang disebut juga dengan work engagement adalah keadaan dimana seseorang mampu berkomitmen dengan organisasi baik secara emosional maupun secara intelektual (Lockwood, 2007). Schaufeli dan Bakker (2004) mendeskripsikan work engagement sebagai pernyataan pikiran yang positif dan pemenuhan yang terkait dengan pekerjaan dan pengalaman yang menyenangkan bagi para karyawan. Hal tersebut datang bersamaan dengan perasaan mengenai semangat (vigour), dedikasi (dedication) dan penghayatan (absorption). Pendapat lain mengenai work engagement adalah sikap positif yang dimiliki oleh pekerja terhadap organisasi dan nilai-nilai yang berada di dalamnya. Pekerja yang engaged menyadari konteks bisnis dan kerja dengan rekan- rekannya sesama pekerja untuk meningkatkan kinerja dalam pekerjaan untuk kepentingan organisasi (Robinson, Perryman dan Hayday, 2004). 
Penelitian sebelumnya yang dilakukan oleh Schaufeli dan Bakker (2004) menunjukkan bahwa sikap positif terhadap pekerjaan seperti kepuasan kerja, keterlibatan kerja, komitmen organisasi dan rendahnya niat untuk keluar berhubungan dengan work engagement. Hasil dari penelitian ini menunjukkan bahwa individu tidak hanya tertarik terhadap aspek pekerjaan yang memberi makna tetapi mereka secara aktif mencarinya dalam pekerjaan mereka sebagai sarana untuk tetap berkomitmen terhadap organisasi. Selain itu, Field and Buitendach (2011) berpendapat bahwa work engagement memiliki hubungan korelasional dan prediktif dengan komitmen organisasi. Komitmen organisasi adalah hasil penting di tempat kerja (Field \& Buitendach, 2011) dan work engagement sangat terkait dengannya. Penelitian lain juga menjelaskan bahwa work engagement memediasi hubungan antara anteseden atau karakteristik pekerjaan dan hasil kerja positif seperti komitmen organisasi (Saks, 2006). Dari beberapa penelitian yang telah diuraikan di atas menunjukkan bahwa work engagement diperlukan bagi karyawan, mengingat work engagement dapat berfungsi sebagai prediktor munculnya perilaku positif karyawan di dalam organisasi seperti komitmen organisasi.

Dalam penelitian ini, peneliti ingin melakukan penelitian untuk melihat gambaran work engagement karyawan di PT EG. Peneliti memilih karyawan PT EG karena peneliti melihat adanya isu yang menarik yang terjadi pada PT EG, dimana sebagian karyawan tampak kurang bersemangat dalam bekerja. Misalnya ketika mereka sampai di ruangan kerja, mereka tidak langsung menyiapkan jadwal atau agenda yang harus diselesaikan pada hari tersebut, sering menunda-nunda pekerjaan, mengobrol berbagai hal di luar pekerjaan, kurang antusias dalam menyelesaikan pekerjaan dan sebagian ada yang menyudahi pekerjaan dan bergegas untuk pulang meskipun waktu belum tepat menunjukkan waktu pulang.

Meskipun demikian ada sebagian karyawan yang bersemangat dalam menyiapkan dirinya menghadapi hari tersebut, antusias dalam menyelesaikan pekerjaan, dan pada saat istirahat tampak ada karyawan yang masih berkutat dengan pekerjaan dan bersedia pulang larut malam atau dengan kata lain karyawan sulit untuk lepas dari pekerjaan yang sedang dihadapinya.

Fenomena tersebut dalam psikologi industri dan organisasi disebut dengan istilah work engagement (keterikatan kerja). Keterikatan kerja dapat diartikan sebagai kualitas hubungan antara individu dengan pekerjaannya. Karyawan yang memiliki work engagement yang tinggi maka akan menunjukkan tingkah laku yang berorientasi pada tujuan, tekun dalam mencapai sesuatu dengan penuh semangat, serta antusias, bermakna dan bangga terhadap apa yang telah dilakukan (Salanova dan Schaufeli, 2008). Sebaliknya, bagi karyawan yang memiliki work engagement yang rendah maka akan menunjukkan sikap kurang peduli terhadap pekerjaan, sulit berkonsentrasi, kurang antusias, dan cenderung menggunakan waktu kerja dengan melakukan hal-hal yang kurang produktif.

Melihat adanya perbedaan work engagement pada karyawan di PT EG dan adanya indikasi dengan adanya masalah work engagement yang rendah yang ditunjukkan pada perilaku seperti yang dijelaskan di atas, maka peneliti ingin melakukan penelitian yang bertujuan untuk mengetahui gambaran work engagement karyawan di PT EG. 


\section{TEORI}

\section{Work Engagement}

Dalam penelitian ini akan digunakan pengertian work engagement yang dikembangkan oleh Schaufeli dan Bakker (2004). Work engagement didefinisikan Schaufeli dan Bakker (2004) sebagai berikut :

"a positive, fulfilling, work-related state of mind that is characterized by vigor, dedication, and absorption. Rather than a momentary and specific state, engagement refers to a more persistent and pervasive affective-cognitive state that is not focused on any particular object, event, individual, or behavior."

Definisi tersebut menjelaskan, work engagement adalah kondisi pikiran yang positif dan berkaitan dengan pekerjaan yang dicirikan dengan vigor, dedication dan absorption. Vigor (semangat) merujuk pada tingkat energi dan mental yang kuat selama bekerja, keberanian untuk berusaha sekuat tenaga dalam menyelesaikan suatu pekerjaan, dan tekun dalam menghadapi kesulitan kerja. Dedication (dedikasi) berarti merasa terlibat sangat kuat dalam suatu pekerjaan dan mengalami rasa kebermaknaan, antusiasme, kebanggaan, inspirasi dan tantangan. Absorption (penghayatan) dapat digambarkan sebagai konsentrasi penuh di tempat kerja dan sebagai pengalaman yang membahagiakan dalam karyawanan. Engagement yang diungkapkan Schaufeli dan Bakker (2004) ini tidak merujuk pada kondisi yang sesaat dan spesifik, tetapi lebih pada kondisi afektif-kognitif yang terus berlanjut dan nyata, yang tidak terfokus pada objek, situasi, kondisi atau tingkah laku.

Kahn (1990) mendefinisikan engagement sebagai penguasaan karyawan sendiri terhadap peran mereka dalam pekerjaan, dimana mereka akan mengikat diri dengan pekerjaannya, kemudian akan bekerja dan mengekspresikan diri secara fisik, kognitif dan emosional selama memerankan performanya. Selanjutnya, Brown (dalam Robbins, 2003) memberikan definisi work engagement yaitu dimana seorang karyawan dikatakan work engagement dalam pekerjaannya apabila karyawan tersebut dapat mengidentifikasikan diri secara psikologis dengan pekerjaannya, dan menganggap kinerjanya penting untuk dirinya selain untuk organisasi.

Berdasarkan pengertian di atas, dapat disimpulkan bahwa work engagement adalah keadaan motivasional yang positif dan adanya pemenuhan diri dalam pekerjaan yang dikarakteristikkan dengan adanya vigor (kekuatan), dedication (dedikasi), dan absorption (absorpsi).

\section{METODE PENELITIAN}

Metode penelitian ini adalah penelitian kuantitatif karena data yang akan digunakan dalam penelitian ini didapat dari skor work engagement. Teknik sampling yang digunakan purposive (non probability sampling). Secara lebih spesifik, desain yang akan digunakan adalah convenience sampling, yaitu berdasarkan kesediaan partisipan untuk mengisi kuesioner (Graveter dan Forzano, 2009). Selain itu, untuk lebih memudahkan pencarian partisipan, digunakan pula snowball sampling (Kumar, 2005) sebelumnya peneliti terlebih dahulu mencari partisipan yang memenuhi karakteristik penelitian dan kemudian meminta bantuan partisipan tersebut. Untuk mengumpulkan data yang diperlukan dalam penelitian ini akan digunakan kuesioner dan diberikan kepada partisipan yaitu karyawan PT EG secara online atau melalui e-mail. Jumlah responden adalah 101 karyawan yang terdiri dari rentan usia partisipan adalah usia 21-50 tahun.

Dalam penelitian ini digunakan alat ukur yaitu kuesioner Work Engagement yang merupakan adaptasi dan pengembangan dari Utrech Work Engagement Scale (UWES) yang berisi 17 butir pernyataan, dengan 7 item pada dimensi vigour, 4 item pada dimensi dedication, dan 6 item pada 
dimensi absorption. Skala pengukuran yang digunakan adalah skala Likert dimulai dari 1 (tidak pernah) sampai 7 (selalu). Uji realibilitas dilakukan pada masing-masing dimensi work engagement, setiap dimensi memiliki nilai reliabilitas yang baik. Koefisien reliabilitas internal dari dimensi work engagement vigour $=0,826$, dimensi work engagement dedication $=0,781$, dan dimensi work engagement absorption $=0,666$. Selanjutnya gambaran responden yang terdiri dari aspek usia, jenis kelamin, status dan masa kerja yang dapat dilihat pada table 1.

Tabel 1. Gambaran responden berdasarkan aspek jenis kelamin, usia, status dan masa kerja

\begin{tabular}{|c|c|c|c|c|}
\hline No & \multicolumn{2}{|c|}{ Aspek } & Jumlah & Persentase \\
\hline \multirow{2}{*}{1.} & \multirow{2}{*}{ Jenis Kelamin } & Laki-laki & 64 & $63.40 \%$ \\
\hline & & Perempuan & 37 & $36.60 \%$ \\
\hline \multirow{5}{*}{2.} & \multirow{5}{*}{ Usia } & Total & 101 & $100 \%$ \\
\hline & & $21-30$ & 35 & $34.70 \%$ \\
\hline & & $31-40$ & 46 & $45.50 \%$ \\
\hline & & $41-50$ & 20 & $19.80 \%$ \\
\hline & & Total & 101 & $100 \%$ \\
\hline \multirow{2}{*}{3.} & \multirow{2}{*}{ Status } & Kawin & 71 & $70.30 \%$ \\
\hline & & Tidak Kawin & 30 & 29.7 \\
\hline \multirow{5}{*}{4.} & \multirow{5}{*}{ Masa Kerja } & Total & 101 & $100 \%$ \\
\hline & & $<5$ & 67 & $66.30 \%$ \\
\hline & & $5-10$ & 19 & $18.80 \%$ \\
\hline & & $>10$ & 15 & $14.90 \%$ \\
\hline & & Total & 101 & $100.00 \%$ \\
\hline
\end{tabular}

\section{HASIL DAN PEMBAHASAN}

\section{Gambaran Work Engagement}

Untuk mengetahui gambaran work engagement karyawan di PT EG, peneliti melakukan pembagian kedalam 3 kategori sebagai berikut : $1-<3=$ rendah , $3-<5=$ rata-rata, $5-7=$ tinggi. Berikut adalah gambaran work engagement pada karyawan di PT EG, nilai rata-rata vigour tinggi $(\mathrm{M}=5,676)$, nilai rata-rata dedication tinggi $(\mathrm{M}=5,715)$, dan nilai rata-rata absorption tinggi $(\mathrm{M}=5,36)$ yang dapat dilihat pada table 2 .

Tabel 2. Gambaran work engagement karyawan di PT EG

\begin{tabular}{cccc}
\hline No & Dimensi Work Engagement & Mean (Skala 1-7) & Kategori \\
\hline 1 & Vigour & 5.67 & Tinggi \\
2 & Dedication & 5.71 & Tinggi \\
3 & Absorption & 5.36 & Tinggi \\
& Total & 5.57 & Tinggi \\
\hline
\end{tabular}

Jika dicermati data dari setiap dimensi, terlihat bahwa karyawan PT EG memiliki gambaran work engagement yang relatif sama yaitu dimensi vigour tinggi, dedication tinggi dan absorption yang tinggi. Dari penelitian ini ditemukan dimensi work engagement yang paling tinggi yang dimiliki oleh karyawan di PT EG adalah dimensi vigour, yang berarti bahwa karyawan merasa 
bersemangat, merasa kuat dan bertenaga serta merasa mampu mengatasi tekanan-tekanan yang dirasakan ditempat kerja.

Dimensi work engagement yang memiliki skor tinggi ke dua adalah dimensi absorption yang berarti bahwa karyawan merasa waktu berlalu begitu cepat, sangat berkonsentrasi mupun tekun ketika mengerjakan tugas.

Selanjutnya diikuti oleh dan dimensi dedication, yang berarti bahwa karyawan merasa memiliki makna dan manfaat yang jelas dari pekerjaannya, merasa bangga dan merasa pekerjaannya menantang maupun mendapatkan inspirasi dari pekerjaan yang dilakukan.

Peneliti juga melakukan analisa tambahan terhadap beberapa kriteria yang dikumpulkan. Hasil analisis tambahan diperoleh dari hasil analisis deskriptif nilai rata-rata dimensi work engagement dari beberapa aspek.

Tabel 3. Hasil analisis nilai rata-rata dimensi work engagement dilihat dari beberapa aspek

\begin{tabular}{|c|c|c|c|c|c|c|}
\hline \multirow{2}{*}{ No } & \multirow{2}{*}{\multicolumn{2}{|c|}{ Aspek }} & \multirow{2}{*}{$\mathrm{N}$} & \multicolumn{3}{|c|}{ Mean } \\
\hline & & & & Vigour & Dedication & Absorption \\
\hline \multirow{4}{*}{1} & Jenis & Laki-laki & 64 & 5.78 & 5.80 & 5.42 \\
\hline & Kelamin & Perempuan & 37 & 5.50 & 5.57 & 5.26 \\
\hline & & Total & 101 & 5.68 & 5.72 & 5.36 \\
\hline & & $21-30$ & 35 & 5.35 & 5.37 & 5.12 \\
\hline \multirow[t]{3}{*}{2} & Usia & $31-40$ & 46 & 5.80 & 5.80 & 5.44 \\
\hline & & $41-50$ & 20 & 5.96 & 6.13 & 5.60 \\
\hline & & Total & 101 & 5.68 & 5.72 & 5.36 \\
\hline \multirow{4}{*}{3} & Status & Kawin & 71 & 5.84 & 5.89 & 5.50 \\
\hline & Status & Tidak Kawin & 30 & 5.29 & 5.32 & 5.03 \\
\hline & & Total & 101 & 5.68 & 5.72 & 5.36 \\
\hline & & $<5$ & 67 & 5.63 & 5.64 & 5.36 \\
\hline \multirow[t]{3}{*}{4} & Masa Kerja & $5-10$ & 19 & 5.77 & 5.82 & 5.19 \\
\hline & & $>10$ & 15 & 5.74 & 5.92 & 5.56 \\
\hline & & Total & 101 & 5.68 & 5.72 & 5.36 \\
\hline
\end{tabular}

Pada tabel 3 dapat dilihat perbandingan nilai rata-rata dimensi work engagement pada karyawan di PT EG. Pada dimensi vigour, dapat dilihat perbandingan nilai rata-rata terhadap aspek jenis kelamin, hasilnya laki-laki memiliki nilai rata-rata vigour 5.78 yang berarti lebih tinggi dari nilai rata-rata perempuan 5.50. Pada aspek rentang usia, usia 41-50 memiliki nilai rata-rata vigour 5.96 yang berarti lebih tinggi dari nilai rata-rata usia 31-40 dengan nilai rata-rata 5.80 dan usia 21-30 dengan nilai rata-rata 5.35. Pada aspek status pernikahan, status yang menikah memiliki nilai rata-rata vigour 5.84 yang berarti lebih tinggi dibandingkan nilai rata-rata yang berstatus belum menikah 5.29. Dan pada aspek masa kerja, masa kerja 5-10 tahun memiliki nilai rata-rata vigour 5.77 yang berarti paling tinggi dibandingkan dengan masa kerja $>10$ tahun sebesar 5.74 maupun yang memiliki masa kerja $<5$ tahun sebesar 5.63. 
Pada dimensi dedication, dapat dilihat perbandingan nilai rata-rata terhadap aspek jenis kelamin, hasilnya laki-laki memiliki nilai rata-rata dedication 5.80 yang berarti lebih tinggi dari nilai ratarata perempuan 5.57. Pada aspek rentang usia, usia 41-50 memiliki nilai rata-rata dedication 6.13 yang berarti lebih tinggi dari nilai rata-rata usia 31-40 dengan nilai rata-rata 5.80 dan usia 21-30 dengan nilai rata-rata 5.37. Pada aspek status pernikahan, status yang menikah memiliki nilai rata-rata dedication 5.89 yang berarti lebih tinggi dibandingkan nilai rata-rata yang berstatus belum menikah 5.32. Dan pada aspek masa kerja, masa kerja masa kerja $>10$ tahun memiliki nilai rata-rata dedication 5.92 yang berarti paling tinggi dibandingkan dengan masa kerja 5-10 tahun sebesar 5.82 maupun yang memiliki masa kerja $<5$ tahun sebesar 5.64.

Pada dimensi absorption, dapat dilihat perbandingan nilai rata-rata terhadap aspek jenis kelamin, hasilnya laki-laki memiliki nilai rata-rata absorption 5.42 yang berarti lebih tinggi dari nilai ratarata perempuan 5.26. Pada aspek rentang usia, usia 41-50 memiliki nilai rata-rata absorption 5.60 yang berarti lebih tinggi dari nilai rata-rata usia 31-40 dengan nilai rata-rata 5.44 dan usia 21-30 dengan nilai rata-rata 5.12. Pada aspek status pernikahan, status yang menikah memiliki nilai rata-rata absorption 5.50 yang berarti lebih tinggi dibandingkan nilai rata-rata yang berstatus belum menikah 5.03. Dan pada aspek masa kerja, masa kerja $>10$ tahun memiliki nilai rata-rata absorption 5.56 yang berarti paling tinggi dibandingkan dengan masa kerja $<5$ tahun sebesar 5.36 dan dengan masa kerja 5-10 tahun sebesar 5.19.

Selain itu peneliti juga melihat gambaran variabel work engagement dalam beberapa aspek. Data diolah dengan menggunakan metode independent sample t test dan one way anova dengan aplikasi SPSS. Berdasarkan jenis kelamin, diperoleh hasil skor sig. $(2$ tailed $)=0.145$ dan 0.172 , karena sig. > 0.05, maka dapat diartikan bahwa tidak ada perbedaan work engagement antara subyek laki-laki dan perempuan, subyek laki-laki memiliki jumlah mean $=5.65$ dan subyek perempuan memiliki jumlah mean $=5.43$. Untuk lebih jelas, dapat dilihat pada tabel 4 .

Tabel 4. Gambaran work engagement berdasarkan jenis kelamin

\begin{tabular}{|c|c|c|c|c|}
\hline & & \multicolumn{3}{|c|}{ t-test for Equality of Means } \\
\hline & & $\mathrm{t}$ & df & Sig. (2-tailed) \\
\hline \multirow{2}{*}{ WE } & $\begin{array}{l}\text { Equal variances } \\
\text { assumed }\end{array}$ & 1.470 & 99 & .145 \\
\hline & $\begin{array}{l}\text { Equal variances not } \\
\text { assumed }\end{array}$ & 1.383 & 62.401 & .172 \\
\hline
\end{tabular}

Berdasarkan status pernikahan, diperoleh hasil skor sig. $(2$ tailed $)=0.01$ dan 0.01 , karena sig. < 0.05, maka dapat diartikan bahwa terdapat perbedaan work engagement antara subyek yang menikah dan yang belum menikah, subyek dengan status menikah memiliki jumlah mean $=5.73$ dan subyek yang belum menikah memiliki jumlah mean $=5.20$. Untuk lebih jelas, dapat dilihat pada tabel 5 . 
Tabel 5. Gambaran work engagement berdasarkan status pernikahan

\begin{tabular}{llccc}
\hline & & \multicolumn{3}{c}{$\mathrm{t}$-test for Equality of Means } \\
\cline { 3 - 5 } WE & $\mathrm{t}$ & $\mathrm{df}$ & $\mathrm{S}$ Sig. (2-tailed) \\
& $\begin{array}{l}\text { Equal variances } \\
\text { assumed }\end{array}$ & 3.421 & 99 & .001 \\
$\begin{array}{l}\text { Equal variances not } \\
\text { assumed }\end{array}$ & 3.529 & 58.651 & .001 \\
\hline
\end{tabular}

Berdasarkan usia, diperoleh hasil skor sig. $(2$ tailed $)=0.007$, karena sig. $<0.05$, maka dapat diartikan bahwa terdapat perbedaan work engagement berdasarkan usia, subyek yang berusia 2130 memiliki jumlah mean $=5.27$, usia $31-40$ memiliki jumlah mean 5.67, dan usia 41-50 memiliki jumlah mean 5.87. Untuk lebih jelas, dapat dilihat pada tabel 6 .

Tabel 6. Gambaran work engagement berdasarkan usia

\begin{tabular}{lrrrrr}
\hline & $\begin{array}{l}\text { Sum of } \\
\text { Squares }\end{array}$ & df & $\begin{array}{c}\text { Mean } \\
\text { Square }\end{array}$ & F & Sig. \\
\hline Between Groups & 5.358 & 2 & 2.679 & 5.207 & .007 \\
Within Groups & 50.423 & 98 & .515 & & \\
Total & 55.781 & 100 & & & \\
\hline
\end{tabular}

Berdasarkan masa kerja, diperoleh hasil skor sig. $(2$ tailed $)=0.711$, karena sig. $>0.05$, maka dapat diartikan bahwa tidak ada perbedaan work engagement pada aspek masa kerja, subyek dengan masa kerja $<5$ tahun memiliki jumlah mean $=5.53$, masa kerja 5-10 memiliki jumlah mean 5.57 dan subyek dengan masa kerja $>10$ tahun memiliki mean $=5.71$. Untuk lebih jelas, dapat dilihat pada tabel 7 .

Tabel 7. Gambaran work engagement berdasarkan masa kerja

\begin{tabular}{lrrrrrr}
\hline & $\begin{array}{c}\text { Sum of } \\
\text { Squares }\end{array}$ & df & $\begin{array}{c}\text { Mean } \\
\text { Square }\end{array}$ & F & Sig. \\
\hline Between Groups & .388 & 2 & .194 & .343 & .711 \\
Within Groups & 55.394 & 98 & .565 & & \\
Total & 55.781 & 100 & & & \\
\hline
\end{tabular}

\section{KESIMPULAN DAN SARAN}

\section{Kesimpulan}

Berdasarkan hasil pengolahan data dan analisa pembahasan mengenai work engagement, diperoleh kesimpulan berikut : 
Dari 101 karyawan yang menjadi responden penelitian, menunjukkan bahwa tingkat work engagement di antara karyawan di PT EG tinggi $(\mathrm{M}=5.57)$. Hal ini menunjukkan bahwa semua karyawan merasa engage, yang berarti mereka bisa mencapai tujuan mereka, sehingga dapat memberi dampak pada keberhasilan PT. EG.

Dimensi work engagement yang paling tinggi yang dimiliki oleh karyawan PT EG adalah dimensi dedication $(\mathrm{M}=5.71)$ yang berarti bahwa karyawan merasa memiliki makna dan manfaat yang jelas dari pekerjaannya, merasa bangga dan merasa pekerjaannya menantang maupun mendapatkan inspirasi dari pekerjaan yang dilakukan. Dimensi work engagement yang memiliki skor tinggi ke dua adalah dimensi vigour $(\mathrm{M}=5.67)$ yang berarti bahwa karyawan merasa bersemangat, merasa kuat dan bertenaga serta merasa mampu mengatasi tekanan-tekanan yang dirasakan ditempat kerja. Selanjutnya diikuti oleh dimensi absorption $(\mathrm{M}=5.36)$ yang berarti bahwa karyawan merasa waktu berlalu begitu cepat, sangat berkonsentrasi mupun tekun ketika mengerjakan tugas.

Bila dilihat dari jenis kelamin, tampak bahwa tidak terdapat perbedaan skor rata-rata work engagement yang signifikan antara laki-laki dan perempuan. Hal ini sesuai dengan penelitian yang dilakukan oleh Drake (2012) yang menemukan tidak ada hubungan antara jenis kelamin dengan keterikatan (engagement) seseorang dengan pekerjaannya. Pada aspek status pernikahan, tampak bahwa terdapat perbedaan skor rata-rata work engagement yang signifikan antara subyek yang menikah dengan yang belum menikah, dimana subyek yang menikah memiliki work engagement yang lebih tinggi dibandingkan yang belum menikah.

Pada aspek usia, tampak bahwa terdapat perbedaan skor rata-rata work engagement yang signifikan antara subyek yang memiliki usia 21-30, 31-40 dan 41-50. Usia 41-50 memiliki skor rata-rata work engagement yang lebih tinggi dibandingkan dibandingkan dengan usia dibawah 41-50 tahun. Hal ini sesuai dengan penelitian yang dilakukan Schaufeli dan Bakker (2003), yang menjelaskan bahwa semakin tua karyawan maka akan semakin memiliki keterikatan (engagement) dengan pekerjaannya. Pada aspek masa kerja, tampak bahwa tidak terdapat perbedaan skor rata-rata yang signifikan antara masa kerja $<5$ tahun, 5-10 tahun dan $>10$ tahun. Meskipun demikian, karyawan yang memiliki masa kerja $>10$ tahun memiliki skor rata-rata work engagement yang lebih tinggi dibandingkan dengan masa kerja dibawah 10 tahun. Hal ini berarti, work engagement dapat meningkat sejalan dengan bertambahnya masa kerja. Hal ini sejalan dengan penelitian yang dilakukan oleh Schaufeli, Bakker dan Salanova (2006) yang menemukan ada hubungan positif antara masa kerja dan work engagament.

\section{Saran}

Berdasarkan penelitian yang telah dilakukan, peneliti mengajukan beberapa saran metodologis dan saran praktis untuk menjadi bahan pertimbangan bagi penelitian selanjutnya.

Dalam penelitian selanjutnya, diharapkan lebih memperhatikan data demografis, seperti atar belakang pendidikan, status kerja partisipan (tetap atau kontrak), posisi atau jabatan yang dimiliki agar memperoleh hasil penelitian yang lebih kaya dan dapat melihat perbedaan dari masing-masing variabel tersebut.

1. Memperbanyak jumlah responden yang dilibatkan dalam penelitian agar hasil yang diperoleh dapat lebih akurat. 
2. Melakukan penelitian lanjutan mengenai work engagement untuk dapat memperoleh informasi yang lebih mengenai aspek-aspek apa saja yang dapat mempengaruhi work engagement, misal iklim dan budaya organisasi, persepsi terhadap dukungan organisasi.

3. Dalam menyelesaikan tugasnya, karyawan diharapkan memiliki keterikatan terhadap pekerjaannya. Berdasarkan hasil penelitian yang sudah dilakukan, diharapkan dapat digunakan sebagai rekomendasi terutama bagi PT EG untuk dapat mempertahankan atau meningkatkan work engagement yang dimiliki olah karyawan dengan memberikan kenyamanan, serta memastikan keamanan karyawan selama bekerja, sehingga kinerja karyawan meningkat dan berdampak pada kemaujuan PT EG.

\section{Ucapan Terima Kasih}

Peneliti mengucapkan terima kasih pada manajemen PT EG yang sudah memberikan ijin pada peneliti untuk melakukan pengambilan data penelitian. Peneliti juga mengucapkan terimakasih dan apresiasi karyawan PT EG yang telah bersedia untuk menjadi responden penelitian ini.

\section{REFERENSI}

Drake, T. J. (2012). Assessing employee engagement: A comparison of the job engagement scale and the Utrech work engagament scale. Available from ProQuest Dissertations and Theses database.(UMI No. 1516919)

Field, L. K., \& Buitendach, J. H. (2011). Happiness, work engagement and organisational commitment of support staff at a tertiary education institution in South Africa. South African Journal of Industrial Psychology, 37, 68-77.

Gravetter, F. J., \& Forzano, L. A. (2009). Research methods for the behavioral sciences ( ${ }^{\text {rd }}$ ed.). Canada, CA: Wadsworth Cengage Learning.

Khan, W. A. (1990). Psychological condition of personal engagement and disangement at work. Academy of Management Journal, 33(4), 692-724.

Kumar, R. (2005). Research methodology: A step by step guide for beginners (2 ${ }^{\text {nd }}$ ed.). London, UK: Sage Publication.

Lockwood, N. R. (2007). Leveraging employee engagement for competitive advantage: HR's strategic role (SHRM Research Quarterly Report). Alexandria, VA: Society for Human Resource Management.

Robinson, D. Perryman S. \& Hayday, S. (2004). The Drivers of Employee Engagement. Institute for Employment Studies.

Saks, A. M. (2006). Antecedents and consequences of work engagement. Journal of Managerial Psychology, 21, 600-619. http://dx.doi. org/10.1108/02683940610690169

Salanova, M. \& Schaufeli, W.B. (2008). Job resources, engagement and proactive behaviour. International Journal of Human Resource Management, 19, 116-131.

Schaufeli, W., \& Bakker, A. (2003). UWES Utrecht Work Engagement Scale. Preliminary Manual (Version 1, November 2003). Utrecht University: Occupational Health Psychology Unit. Retrieved from http://www.beanmanaged.eu

Schaufeli, W.B. \& Bakker, A.B. (2004). Job demands, job resources, and their relationship with burnout and engagement: A multi-sample study. Journal of Organizational Behavior, 25, 293-315.

Schaufeli, W.B., \& Bakker, A.B., \& Salanova, M. (2006). The measurement of work engagement with a short questionnaire: A cross-national study. Educational and Psychological Measurement, 66, 701-716. 